\title{
Atıl Kapasite, Tam Kapasite ve Kapasite Fazlası Üretim Düzeylerinde TMS-2 Stoklar Standardına Göre Maliyetleme: Bir Örnek Uygulama*
}

\author{
Yavuz KILINÇ * \\ Ahmet Cemkut BADEM **
}

\section{$\ddot{O Z E T}$}

Üretim maliyeti unsurları olan direkt ilk madde ve malzeme, direkt işçilik maliyeti ve genel üretim giderlerinin mamullere yüklenmesi konusunda muhasebe yazınında geliştirilen çeşitli yöntemler bulunmaktadır. Bu yöntemlerden tam maliyet yönteminin uygulama kolaylığı nedeniyle çokça kullanıldığı görülmektedir. Ancak Uluslararası/Türkiye Muhasebe Standartları ise duruma farkl yaklaşmaktadır. UMS/TMS-2 Stoklar Standardı'na göre bazı durumlarda normal maliyet yönteminin kullanılması gerekmektedir. Ancak Standart bir bütün olarak incelendiği zaman üretim düzeylerine göre kullanılacak maliyet yöntemine ilişkin farklı görüsleri barındırdiğı görülmektedir. Bu çalışmada üretim düzeyi ile normal kapasite arasındaki ilişki gözetilerek öne sürülen bu farklı görüşler detaylı olarak incelenmiş, Stoklar Standardı'nın işletmelerin gerçekleşen kapasite düzeyine göre hangi maliyet yöntemini kullanması gereğine ilişkin görüşleri örnek uygulama üzerinden tartışılmıştır.

Anahtar Kelimeler: TMS-2 Stoklar Standard, Normal Kapasite, Tam Maliyet Yöntemi, Normal Maliyet Yöntemi

JEL Sinıflandirması: M41, M49
\end{abstract}

\section{Costing At Idle Capacity, Full Capacity And Excess Capacity Production Levels} According To The TAS-2 Inventories Standard: An Example Application

\section{ABSTRACT}

In accounting literature, there are various methods about loading direct materials, direct labor and overhead costs which are counted as production cost elements to products. It is seen that full cost method of these methods are used more frequent due to the ease of implementation. On the other hand, International / Turkish Accounting Standards approach the situation differently. In accordance with the IAS/TMS-2 Inventories Standard, the normal cost method should be used in some cases. However, when the standard is examined as a whole, it is observed that there are different views in the standard regarding the cost method to be used according to production levels. In this study, these different views, which are put forward by considering the relationship between production level and normal capacity, were examined in detail. As a result, the views of the Inventories Standard regarding the cost method are discussed according to the capacity level of the enterprises through the sample application.

Keywords: TAS-2 Inventories Standard, Normal Capacity, The Full Cost Method, The Normal Cost Method

Jel Classification: M41, M49

\footnotetext{
* Makale Gönderim Tarihi: 10.10.2019, Makale Kabul Tarihi: 03.12.2019, Makale Türü: Örnek Olay (Vaka Analizi)

* Arş. Gör. Dr., Kocaeli Üniversitesi, İktisadi ve İdari Bilimler Fakültesi, yavuzkilinc25@gmail.com, ORCID ID: 0000-0001-7545-8663

** Doç. Dr., Kocaeli Üniversitesi, İktisadi ve İdari Bilimler Fakültesi, cemkutbadem@hotmail.com, ORCID ID: 0000-0001-5961-5742
} 


\section{GİRiş}

Bilindiği üzere üretilen mamullerin maliyeti üç ana unsurdan meydana gelmektedir. Bunlar; direkt ilk madde ve malzeme, direkt işçilik ve genel üretim giderleridir. Direkt ilk madde ve malzeme ile direkt iş̧̧ilik giderleri doğrudan mamulün bünyesine katılırken; genel üretim giderleri mamulün bünyesine dolaylı olarak katılabilmektedir. Literatürde sıklıkla tartışılan önemli konulardan birisi de mamulün bünyesine katılacak olan bu üretim maliyeti unsurlarından hangilerinin olması veya olmamasıdır. Literatürde yapılan konu ile ilgili tartışmalar çeşitli maliyetlendirme yöntemlerinin geliştirilmesini sağlamıştır. Genel itibari ile bu yöntemler; i) tam maliyet yöntemi, ii) değişken maliyet yöntemi, iii) normal maliyet yöntemi ve iv) asal (ilk) maliyet yöntemi olarak sınıflandırılmıştır. (Büyükmirza, 2012:493494) Ayrıca bu dört yöntemin yanı sıra uluslararası muhasebe yazınında "super variable costing" veya throughput costing" gibi kavramlarla açıklanan beşinci bir maliyet yöntemi daha vardır. Bu maliyet yöntemi süper değişken maliyet olarak adlandırılır. (Badem, 2014:32)

Şekil 1'de görüleceği üzere tam maliyet yönteminde üretim maliyeti unsurlarının tamamı mamulün bünyesine girmektedir. Değişken maliyet yönteminde sadece değişken nitelikteki unsurlar mamulün bünyesine dâhil edilirken sabit giderler dönem gideri kabul edilmekte; asal maliyetleme yönteminde sadece direkt ilk madde ve malzeme ile direkt işçilik giderleri dâhil edilmekte, GÜG'lerin tamamı ise dönem gideri olarak kabul edilmektedir. Normal maliyetleme yönteminde ise mamulün bünyesine tüm değişken maliyet unsurları doğrudan dâhil edilirken sabit genel üretim maliyetleri mamul bünyesine kapasiteden yararlanma düzeyine göre dâhil edilmektedir. Yani kullanılmayan kapasiteye düşen sabit GÜG’ler dönem gideri olarak kabul edilir. İleri (süper) değişken maliyet yönteminde ise sadece direkt ilk madde ve malzeme giderleri mamulün bünyesine katılmakta, geriye kalan tüm maliyet unsurları dönem gideri olarak kabul edilir.

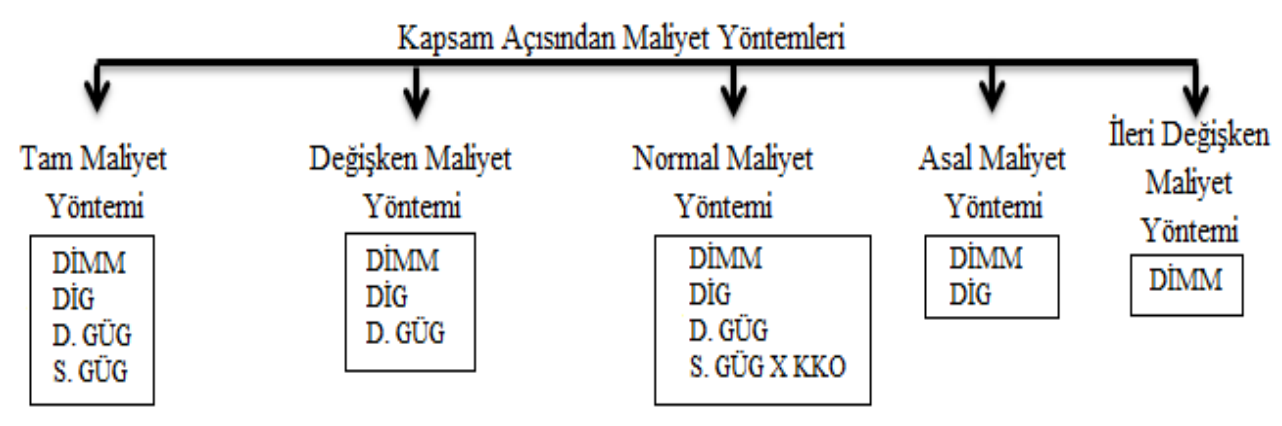

Şekil 1. Kapsam Açısından Maliyet Yöntemleri

Literatürde yer alan bu maliyetleme yöntemlerinden tam maliyet yöntemi dış raporlama için gereklidir (Hansen ve Mowen, 2006:834). Ancak dış raporlama amacına yönelik kârın belirlendiği tam maliyet yöntemi sözgelimi katkı payının gösterilmesi gibi içe dönük karar verme amaçları açısından uygun olmayabilir (Haftacı, 2013:83). Bu nedenle planlama, denetim ve yönetsel kararlar açısından bir gereksinim olan sabit ve değişken maliyet ayrımının yapılmasına olanak tanıyan değişken maliyet yönteminin iç raporlamaya yönelik kullanılabileceği söylenebilir (Haftac1, 2013:87). Ayrıca kârın tespitine yönelik kullanılabilecek bu yöntemler için yasal düzenlemelere ve standartlara bakıldığı zaman 
Türkiye'de Vergi Usul Kanunu açısından vergi matrahının tespitine yönelik tam maliyet yönteminin kullanılması gerektiği görülür. Yani VUK açısından işletmelerin tam maliyet yöntemini kullanmaları esastır (Ö̈ten ve diğ., 2010:47). Vergi matrahının tespiti açısından işletmelerin dış raporlamada tam maliyet yöntemini kullanmaları gerektiği VUK 275. maddesinde şöyle beyan edilmiştir:" İmal edilen emtianın (Tam ve yarı mamul mallar) maliyet bedeli aşăğda yazılı unsurları ihtiva eder:

1. Mamulün vücuda getirilmesinde sarf olunan iptidai ve hammaddelerin bedeli;

2. $\quad$ Mamule isabet eden iş̧̧ilik;

3. Genel imal giderlerinden mamule düssen hisse;

4. Genel idare giderlerinden mamule düşen hisse; (Bu hissenin mamulün maliyetine katılmast ihtiyaridir.)

5. Ambalajli olarak piyasaya arz edilmesi zaruri olan mamullerde ambalaj malzemesinin bedeli.

Mükellefler, imal ettikleri emtianın maliyet bedellerini yukarıdaki unsurları ihtiva etmek şartıyla diledikleri usulde tayin edebilirler." Madde 275 incelendiğinde işletmelere üretim maliyeti unsurlarının tamamının dış raporlamaya yönelik kullanımının zaruri olduğu aşikârdır.

VUK'a göre işletmelerin finansal durum tablosunda gösterecekleri yarı mamul ve mamul stoklarını ve gelir tablosunda gösterecekleri satışlarının maliyetini tam maliyet yöntemini kullanarak göstereceklerdir (Badem ve Özbek, 2013:72).

TMS-2 Stoklar Standardı açısından normal maliyet yönteminin, Büyük ve Orta Boy İşletmeler İçin Finansal Raporlama Standartları (BOBİ FRS) ile hâlihazırda taslak olarak sunulmuş olan Küçük ve Mikro İşletmeler İçin Finansal Raporlama Standartları (KÜMİ FRS) için ise, tam maliyet veya normal maliyet yöntemlerinin kullanılması gerektiği belirtilmiştir.

Tam maliyet yöntemi çoğu ülkede dış raporlamada sıklıkla kullanılan bir stok değerleme yöntemidir. Bu yöntem genellikle işletmeler tarafından kullanım maliyetinin düşük olması ve kârın tespitinin kolayca gerçekleştirilebilmesi gibi nedenlerle dış raporlamanın yanında iç raporlamada da kullanılmaktadır (Horngren vd., 2012:309). Yöntemde, değişken üretim maliyetleri ile sabit üretim maliyetlerinden oluşan tüm maliyet unsurlarını, mamulün maliyetine tamamen katılmaktadır. Bu yönteme göre maliyetler sabit veya değişken ayrıma tabi tutulmadan, üretimle ilişkisine göre mamulün maliyetine yükletilir (Erden, 2004:100). Üretim maliyetlerinin sabit /değişken ayrımı yapılmadığından kullanımı daha kolaydır.

TTK'nın 88. Maddesi ile bilanço usulüne tabi bazı işletmelerin Türkiye Muhasebe ve Finansal Raporlama Standartlarına (TMS/TFRS) uygun olarak muhasebe işlemlerini gerçekleştirmeleri zorunlu hale getirilmiştir. Kamu Gözetim Kurumu tarafindan hazırlanan muhasebe standartlarında mamulün bünyesine katılması gereken unsurlar TMS-2 Stoklar standardınca açıklanmıştır.

TMS-2 Stoklar Standardı'na göre stokların maliyeti; tüm satın alma, dönüştürme ve mevcut durum ve konuma getirilmesi için katlanılan diğer maliyetlerden oluştuğu ifade edilmiştir (TMS, 2: md. 10). Üretim işletmeleri için satın alma maliyeti, gerek direkt gerekse dolaylı ilk madde ve malzemenin satın alınması; dönüştürme maliyeti olarak da ilk madde ve 
malzemenin üretime sokularak mamul haline getirilmesine olanak sağlayacak direkt iş̧ilik ve genel üretim giderleri ifade edilmektedir (Badem ve Özbek, 2013:72). Standartta üretimin üç temel unsurunun doğrudan olmasa bile dolaylı olarak ifade edildiği görülmektedir. Daha önce de belirtildiği gibi burada mamulün maliyetini oluşturan unsurların yanı sıra bu unsurlardan hangilerinin üretilen mamullerin maliyetine dâhil edileceği öne çıkmaktadır. Standart, madde 12 ve 13 'te dönüştürme maliyetleri kavramını daha açarak burada kullanıcıları normal maliyet yöntemine yönlendirmektedir. Şöyle ki madde 12 'de "Stokların dönüştürme maliyetleri; direkt iş̧̧ilik giderleri gibi, üretimle doğrudan ilişkili maliyetleri kapsar. Bu maliyetler ayrıca ilk madde ve malzemenin mamule dönüstürülmesinde katlanılan sabit ve değişken genel üretim giderlerinden sistematik bir şekilde dağıtılan tutarları da içerir. Sabit genel üretim maliyetleri; amortisman, fabrika binası ve teçhizatının bakım onarım giderleri gibi, üretim miktarından băğmsız olarak nispeten sabit kalan dolaylı üretim maliyetleri ile fabrikanın yönetim ve idaresi ile ilgili maliyetlerdir. Değişken genel üretim giderleri, endirekt (dolayll) malzeme ve endirekt (dolayli) iş̧̧ilik gibi, üretim miktarı ile birlikte doğru orantılı olarak değişen dolayl üretim maliyetleridir." ifadelerine yer vermektedir. Bu madde incelendiği zaman standardın üretimle ilgili direkt maliyet unsurlarına vurgu yaptıktan sonra genel üretim giderlerini açıklayarak bu maliyetler üzerinde özellikle durmuştur. Madde 13’te ise standart," Sabit genel üretim maliyetlerinin dönüştürme maliyetlerine dağıttımı, üretim faaliyetlerinin normal kapasitede olacağl varsayımına dayanır. Normal kapasite, planlanan bakım-onarım çalışmalarından kaynaklanacak kapasite düşüklüğü de dikkate alınarak, normal koşullarda bir veya birkaç dönem veya sezonda elde edilmesi beklenen ortalama üretim miktarıdır." ifadeleri ile standart direkt olmasa bile dolaylı olarak normal maliyet yöntemine atıf yapmaktadır (TMS, md:12-13).

\section{LITERATÜR İNCELEMESI}

Muhasebe yazınında Türkiye'deki işletmeleri önemli düzeyde etkilemesinden ve VUK ve TMS/TFRS'lerin farklılaşmasından kaynaklı olarak tam ve normal maliyet yöntemlerinin karşılaşıldığ yazarların çalışmalarının neticelerine yer verilmiştir.

Güngörmüş ve Boyar (2010) tarafindan yapılan çalışmada; normal maliyet, standart maliyet ve tam maliyet yöntemleri karşılaştırılmış ve kapasite kullanımından doğan olumsuz genel üretim maliyetlerinin nasıl muhasebeleştirilmesi gerektiği açıklanmıştır.

Badem ve Özbek (2013) tarafından yapılan çalışmada kapsam açısından maliyetleme yöntemleri tanıtılmış, Türkiye'deki yasal düzenlemelere göre kullanılması gereken yöntemler karşılaştırılmış ve yasal düzenlemeler arasındaki yöntem farklılığın neden olacağı ertelenmiş vergi etkisi ortaya konmuştur.

Marşap ve Barışçı (2014) tarafindan yapılan çalışmada, hem kuramsal açıdan hem de uygulamalı olarak tam ve normal maliyet yöntemleri karş̧laştırılmış, yöntemlerin güçlü ve zayıf yönleri tespit edilerek işletme sahip ve yöneticilerine yönelik öneriler sunulmuştur.

Gökçen ve Öztürk (2017) tarafindan yapılan çalışmada, tam ve normal maliyet yöntemleri karşılaştırmalı olarak incelenmiş, normal maliyet yönteminin kullanımına yönelik olarak TMS/TFRS ile BOBİ FRS'lerdeki düzenlemeler tartışılarak normal maliyet 
yönteminin kullanılabilmesi için işletmelerde nasıl bir maliyet kayıt sisteminin olması gerektiği açıklanmıştır.

Öztürk ve Güleç (2018) tarafından yapılan çalışmada, normal maliyet yönteminin nasıl ortaya çıktığı ve varsayımlarının neler olduğu; bu maliyet yönteminde üretim maliyetinin nasıl hesaplanacağı ve nasıl kaydedileceği açıklanmıştır.

Özyapıcı (2019) tarafından yapılan çalışmada, TMS 2 Stoklar Standardı'nın atıl kapasite analizine etkisi, gerçek ve zorunlu atıl kapasite kavramları ve yönetsel kararların alınabilmesi için ilgili standart ile atıl kapasite kavramlarının birlikte nasıl değerlendirilmesi gerektiği vurgulanmıştır.

Literatür incelemesi dikkate alındığında yapılan çalışmalarda TMS-2 Stoklar Standardı'nın normal maliyet yönteminin kullanımına sınır getirdiği durumlara değinilmediği görülmektedir. Bu sınırlamalar; Standardın madde 13'te ifade ettiği gibi fiili kapasitenin normal kapasiteye yakın olduğu zamanlarda ve normal kapasiteden fazla gerçekleşen üretim miktarının olduğu dönemlerde normal maliyet yöntemi yerine tam maliyet yöntemine geçilmesini ifade ettiği bölümlerdir. Yapılan bu çalışmada Standardın normal maliyetleme yöntemine ilişkin olarak getirdiği bu sınırlamalar ve sınırlamaların oluşturacağı etkilerin gerekçeleri tartışılmıştır.

\section{NORMAL MALIYYT YÖNTEMI}

Normal maliyet yöntemi; direkt ilk madde ve malzeme, direkt iş̧̧ilik ve değişken genel üretim giderlerinin oluşturduğu değişken giderlerin tamamının, sabit genel üretim giderlerinin ise kapasite kullanım oranına göre mamullere yüklendiği, kapasite kullanım oranının dışında kalan giderlerinse dönem gideri olarak kabul edildiği yöntemdir (Erden, 2004:101). Normal maliyet yöntemi, sabit genel üretim giderlerinin belirli bir kapasite oluşturmak veya var olan kapasitenin sürdürülebilirliğini sağlamak amacıyla yapıldığını ve bu nedenle söz konusu maliyetlerin üretim maliyetlerine kapasiteden yararlanma ölçüsüne göre yüklenmesi gerektiğini kabul eder (Büyükmirza, 2012:504).

Standardın normal maliyet yöntemine atıf yapması ile birlikte ortaya çıkan önemli sorulardan birisi de normal kapasite ölçüsünün ne olduğudur. TMS-2 madde 13 'te normal kapasite ölçüsünü tanımlamaktadır. Şöyle ki normal kapasite, planlanan bakım-onarım çalışmalarından kaynaklı kapasite düşüklükleri de göz önünde bulundurularak, normal üretim koşullarında bir veya birkaç dönemlik üretim kapasitesinin ortalaması olarak ifade edilmiştir. Sözgelimi A işletmesinin normal üretim koşullarında 2015 yılı üretim miktarı 100.000 birim, 2016 y1lı üretim miktarı 120.000 birim ve 2017 yılı üretim miktarı 140.000 birim olsun. A işletmesinde standardın 13. maddesinden hareketle hesaplanacak ortalama üretim miktarı olan normal kapasite ölçüsü 120.000 birim $((100.000+120.000+140.000) / 3)$ olacaktır.

Ortalama üretim miktarının kapasite ölçüsü olarak kabul edilmesi durumunda, dönemler itibari ile kapasite miktarında meydana gelen dalgalanmalar normal kabul edilir ve normal maliyetin bu dalgalanmalardan etkilenmemesi gerekir. Esasında normal maliyet yönteminin amacı da, kapasite değişikliklerinden birim sabit maliyetin etkilenmemesinin sağlanmasıdır (Büyükmirza, 2012:517). Girdi fiyatlarının ve verimliliğinin değişmediği durumlarda birim üretim maliyetleri, farklı üretim dönemlerinde aynı kalacaktır. Maliyetlerin 
sabit ve değişken ayrımına tabi tutulması, sabit genel üretim maliyetlerinin ne kadarının üretim maliyetine dâhil edileceğinin belirlenmesi için normal kapasitenin hesaplanması ve kapasite sapmalarının hesaplanması gibi işlemler normal maliyeti uygulayan işletmelere ek bir külfet getirecektir. Ancak maliyet muhasebesinin önemine sahip işletmeler için bu tür durumların önemli etkenler olmadığı da rahatlıkla söylenebilir. (Büyükmirza, 2012:504).

\section{NORMAL MALIYET YÖNTEMININ KULLANIMININ SINIRLANDIRILMASI VE AŞIRI KAPASITE KULLANIMI}

\subsection{Genel Açıklama}

Yukarıda da değinildiği gibi TMS-2 Stoklar Standardı sabit genel üretim maliyetlerinin normal kapasite ölçüsüne göre mamulün bünyesine katılması gerektiğini ifade eder. TMS-2 madde 13'de bu durum açıklanarak normal maliyet yönteminin kullanılacağı belirtilmiştir. Ancak ilgili maddenin devamında gerçek üretim düzeyinin normal kapasiteye yakın olması durumunda bu üretim düzeyinin normal kapasite olarak dikkate alınabileceği belirtilmiştir. Bu durum "Gerçek üretim düzeyi normal kapasiteye yakınsa, bu kapasite normal kapasite olarak kabul edilebilir" ifadeleri ile belirtilmiştir. Yani böyle bir durumun gerçekleşmesi halinde işletmenin tam maliyet veya normal maliyet yöntemi kullanması büyük farklılık doğurmaz. Her iki yöntemde de neredeyse aynı maliyet yüklemesi ortaya çıar. Ayrıca madde 13'ün devamında Standart, "çok yüksek üretim olan dönemlerde, her bir üretim birimine dağıtılmış sabit genel üretim maliyeti payı düşer, böylece stoklar yüksek maliyetten değerlenmemiş olur" ifadesine yer verilmiştir. İlk bakışta standardın burada neyi ifade ettiği net bir biçimde anlaşılmamaktadır. Bilindiği gibi TMS/TFRS, Uluslararası Muhasebe ve Finansal Raporlama Standartlarının birebir tercümesidir. Bu nedenle ilgili maddenin bu kısımlarının anlaşılmasında asıl metne bakmakta fayda olduğu düşünülmektedir. Standardın orijinal metninde şu ifadelere yer verilmiştir; "In periods of abnormally high production, the amount of fixed overhead allocated to each unit of production is decreased so that inventories are not measured above cost". Standardın ilgili bu bölümün çevirisinde Badem ve Özbek (2013)'in de çalışmalarında belirttiği üzere, "in periods of abnormally high production" kısmı "anormal düzeyde yüksek üretim dönemlerinde" olarak çevrildiğinde normal kapasitenin üzerinde gerçekleşebilecek üretim düzeyinin kastedildiği anlaşılmaktadır. $\mathrm{Bu}$ nedenle Standardın bu anlatımla normal kapasitenin üstünde gerçekleşen üretim düzeylerinde normal maliyet yönteminin kullanımı yerine tam maliyet yönteminin kullanılması gerektiğini ifade etmektedir. Çünkü tam ve normal maliyet yöntemlerinin karşılaştırılmasında da değinildiği gibi normal maliyet yönteminin tam maliyet yöntemine karşı üstünlüğünün üretim seviyesindeki artış ve azalışlara karşı birim maliyetin değişimine engel olması olduğu belirtilmiştir. Standardın da normalin üzerinde gerçekleşen kapasite seviyelerinde birim mamule düşen sabit genel üretim maliyetinin azaldığını ifade etmesi Standardı uygulayacak olan işletmenin normal maliyet yerine tam maliyet yöntemini kullanması gerektiğini belirtmektedir.

Literatür incelemesi kısmında da değindiğimiz gibi maliyet kapsamını ele alan çalışmalarda genellikle yöntemlerin karşılaştırılması ve olumsuz kapasite sapmalarına değinilmiştir. Ancak standardın madde 13'de ifade ettiği durum esasında olumlu kapasite sapmasıdır. Burada karşımıza çıkan soru olumlu kapasite olması durumunda standardın 
uygulama değişikliğinin etkisi ne olacaktır? Bu sorunun cevaplanmasına ve standardın yöntem değişikliğine başvurmasının etkilerini gösterebilme adına basit bir uygulamaya yer verilmiş̧ir.

\subsection{Uygulama Örneği}

Ortalama aylık normal üretim kapasitesi 10.000 birim olan $\mathrm{ABC}$ işletmesinin bazı verileri aşağıdaki tabloda verildiği gibidir. (Çalışmanın esas amacı yöntemlerin karşılaştırılması değildir. Amaç, Standardın aşırı kapasite kullanımı durumunda normal maliyet yöntemi yerine tam maliyet yönteminin kullanılması gerektiğini belirtmesinden hareketle normal kapasitenin altında, normal kapasiteye yakın ve normal kapasitenin üstü üretim durumlarında yöntemlerin farklılaşması ile raporlanan maliyetlerde ortaya çıkacak farkların gösterilmesi olduğundan dönem başı ve dönem sonu mamul stokun olmadığı varsayımından hareket edilerek anlatımın basitleştirilmesi sağlanmıştır.)

Tablo 1. ABC A.Ş. Üretim-Satış Bilgileri

\begin{tabular}{|l|r|l|r|l|l|}
\hline \multicolumn{2}{|c|}{ Haziran } & \multicolumn{2}{c|}{ Temmuz } & \multicolumn{2}{c|}{ Ăgustos } \\
\hline Üretim & 6.000 br. & Üretim & 9.800 br. & Üretim & 12.000 br. \\
\hline Sat1ş & 6.000 br. & Satış & 9.800 br. & Satış & 12.000 br. \\
\hline Normal Kapasite & 10.000 br. & Normal Kapasite & 10.000 br. & Normal Kapasite & 10.000 br. \\
\hline
\end{tabular}

Tablo 1 incelendiği zaman $\mathrm{ABC}$ işletmesinin Haziran, Temmuz ve Ağustos dönemlerinde üretimini gerçekleştirdiği tüm mamulleri sattığg görülmektedir. Yani işletmemizde dönem başı ve dönem sonu mamul stoku bulunmamaktadır. Ayrıca işletme üretimini gerçekleştirdiği her bir mamulü 1.000 TL'ye satmaktadır. Yapılan hesaplamalarda işletmenin birim direkt ilk madde ve malzeme maliyeti $100 \mathrm{TL}$, birim direkt işçilik maliyeti $50 \mathrm{TL}$, birim değişken genel üretim maliyeti $50 \mathrm{TL}$ ve aylık sabit genel üretim maliyeti ise 1.200.000 TL'dir. Daha öncede belirtildiği gibi işletmenin normal üretim kapasitesi aylık 10.000 birimdir. $\mathrm{Bu}$ açıdan birbirini takip eden yukarıdaki üç üretim dönemine bakıldığında Haziran ayında normal kapasitenin önemli ölçüde altında, Temmuz ayında normal kapasite ile aynı sayılabilecek bir düzeyde ve Ağustos döneminde ise normal kapasiteden yüksek düzeyde üretim yapıldığı görülmektedir. $\mathrm{ABC}$ işletmesinin muhasebe standartlarına ve VUK'a göre hazırlayacağı finansal tablolarında kullanacağ 1 maliyet yöntemlerine göre ortaya çıkacak maliyet ve kâr durumu aşağılda tablo 2 ve 3 'te verildiği gibi olacaktır. 
Tablo 2. Tam Maliyet Yöntemine Göre Maliyet-Kâr Verisi

\begin{tabular}{|c|c|c|c|c|c|c|}
\hline \multicolumn{7}{|c|}{ Tam Maliyet Yöntemi Açısından } \\
\hline & \multicolumn{2}{|c|}{ Haziran } & \multicolumn{2}{|c|}{ Temmuz } & \multicolumn{2}{|c|}{ A ğustos } \\
\hline Satışlar & & 6.000 .000 & & 9.800 .000 & & 12.000 .000 \\
\hline & $(6.000 \times 1.000)$ & & $(9.800 \times 1.000)$ & & $12.000 \times 1.000$ & \\
\hline Satışların Maliyeti & & $(2.400 .000)$ & & $(3.160 .000)$ & & $(3.600 .000)$ \\
\hline DİMM & 600.000 & & 980.000 & & 1.200 .000 & \\
\hline DİG & 300.000 & & 490.000 & & 600.000 & \\
\hline D. GÜG & 300.000 & & 490.000 & & 600.000 & \\
\hline S. GÜG & 1.200 .000 & & 1.200 .000 & & 1.200 .000 & \\
\hline Brüt Satış Kârı & & 3.600 .000 & & 6.640 .000 & & 8.400 .000 \\
\hline Br. Mamul Maliyeti & & 400 & & 322,45 & & 300 \\
\hline
\end{tabular}

ABC işletmesinin tam maliyet yöntemini kullanması durumunda sabit genel üretim maliyetinin 1.200.000 TL olarak her üç ayda da mamulün bünyesine katıldığ görülmektedir. Burada kapasitenin altında veya üstünde üretimin gerçekleşmesi durumu değiştirmemektedir. Böylelikle işletmenin birbirini takip eden üç ayında üretim hacminde meydana gelen artışlar birim mamul maliyetini de düşürmektedir.

Tablo 3. Normal Maliyet Yöntemine Göre Maliyet-Kâr Verisi

\begin{tabular}{|c|c|c|c|c|c|c|}
\hline \multicolumn{7}{|c|}{ Normal Maliyet Yöntemi Açısından } \\
\hline & \multicolumn{2}{|l|}{ Haziran } & \multicolumn{2}{|c|}{ Temmuz } & \multicolumn{2}{|c|}{ Ağustos } \\
\hline Satışlar & & 6.000 .000 & & 9.800 .000 & & 12.000 .000 \\
\hline & $(6.000 \times 1.000)$ & & $(9.800 \times 1.000)$ & & $12.000 \times 1.000$ & \\
\hline Satışların Maliyeti & & $(1.920 .000)$ & & $(3.136 .000)$ & & $(3.840 .000)$ \\
\hline DİMM & 600.000 & & 980.000 & & 1.200 .000 & \\
\hline DİG & 300.000 & & 490.000 & & 600.000 & \\
\hline D. GÜG & 300.000 & & 490.000 & & 600.000 & \\
\hline S. GÜG & $\begin{array}{r}720.000 \\
(1.200 .000 \times 0,60)\end{array}$ & & $\begin{array}{r}1.176 .000 \\
(1.200 .000 \times 0,98)\end{array}$ & & $\begin{array}{r}1.440 .000 \\
(1.200 .000 \times 1,20)\end{array}$ & \\
\hline Brüt Satış Kârı & & 4.080 .000 & & 6.664 .000 & & 8.160 .000 \\
\hline Kapasite Sapması $^{* * *}$ & & $(480.000)$ & & $(24.000)$ & & 240.000 \\
\hline Faaliyet Kârı & & 3.600 .000 & & 6.640 .000 & & 8.400 .000 \\
\hline Br. Mamul Maliyeti & & 320 & & 320 & & 320 \\
\hline Sabit GÜG YO**** & & 120 & & 120 & & 120 \\
\hline
\end{tabular}

\footnotetext{
*** Kapasite Sapması=(Üretim Kapasitesi-Gerçekleşen Üretim)x Sabit GÜG YO

Haziran Kapasite Sapmasi $=(10.000-6.000) \times 120=480.000$ TL $($ Olumsuz $)$

Temmuz Kapasite Sapmasi $=(10.000-9.800) \times 120=24.000$ TL (Olumsuz)

Ağustos Kapasite Sapması $=(10.000-12.000) \times 120=240.000$ TL $($ Olumlu $)$

${ }^{* * * *}$ Sabit GÜG YO= Sabit Genel Üretim Gideri/Normal Üretim Kapasitesi $=1.200 .000 / 10.000=120 \mathrm{TL} / \mathrm{ÜM}$
} 
$\mathrm{ABC}$ işletmesinin maliyet yöntemi olarak normal maliyet yöntemini kullanması durumunda ise işletmenin üretim dönemlerinde mamullerine yükleyeceği değişken nitelikteki maliyetleri aynı kalırken, sabit nitelikteki genel üretim maliyetleri kapasite kullanım düzeyi dikkate alındığından değişmektedir. Esasında bakıldığı zaman tüm veriler aynı olmasına karşlık tam maliyet ve normal maliyet yöntemleri açısından birim mamul maliyetleri değişmektedir. Bu durum tablo 4 'te karş̧laştırılmak suretiyle gösterilmiştir.

Tablo 4. Yöntemlerin Karşılaştırılması

\begin{tabular}{|l|l|r|r|r|r|}
\cline { 3 - 6 } \multicolumn{2}{c|}{} & Tam Maliyet Y. (1) & $\begin{array}{c}\text { Normal Maliyet Y. } \\
\text { (2) }\end{array}$ & Fark (2-1) & $\begin{array}{c}\text { Kapasite } \\
\text { Sapmasi }\end{array}$ \\
\hline \multirow{3}{*}{ Haziran } & Yüklenen Sabit GÜM & 1.200 .000 & 720.000 & -480.000 & Olumsuz \\
\cline { 2 - 6 } & Birim Mamul Maliyeti & 400 & 320 & -80 & \\
\hline \multirow{3}{*}{ Temmuz } & Yüklenen Sabit GÜM & 1.200 .000 & 1.176 .000 & -24.000 & Olumsuz \\
\cline { 2 - 6 } & Birim Mamul Maliyeti & 322,45 & 320 & $-2,45$ & \\
\hline \multirow{3}{*}{ Ăgustos } & Yüklenen Sabit GÜM & 1.200 .000 & 1.440 .000 & 240.000 & Olumlu \\
\cline { 2 - 7 } & Birim Mamul Maliyeti & 300 & 320 & & 20 \\
\hline
\end{tabular}

Tablo 4 incelendiğinde,

- Haziran ayında maliyet yöntemi olarak tam maliyet yönteminin seçilmesi durumunda işletmenin normal kapasiteye göre kapasitesinin sadece \% 60'ını kullanmasından dolayı mamullere $480.000 \mathrm{TL}$ fazla sabit GÜM payı yüklediği görülür. Bu durumda birim mamul maliyetinin $80 \mathrm{TL}$ artmasına yol açar. Ancak Standart böyle bir durumda atıl olan kapasiteye düşen bu 480.000 TL'lik kısmın üretilen mamullere yüklenmemesi gereğini ifade etmektedir.

- Temmuz ayında işletmenin normal kapasiteye göre kapasitenin \% 98'ini kullanması dolayısı ile maliyet bilgisinin birbirine yakın olduğu görülür. Öyle ki tam maliyet yönteminde birim mamul maliyeti sadece 2,45 TL fazla hesaplanmıştır. Standarda göre işletmelerde ortaya çıkabilecek böyle durumlarda yani gerçek üretim miktarının normal kapasiteye yakın olması durumunda her iki yönteminde kullanılabileceğini belirtilmektedir.

- $\quad$ Ağustos ayı ise diğer iki aya göre normal maliyet yönteminin mamullerin maliyetine daha fazla GÜM payı verildiği ay olarak karşımıza çıar. Öyle ki bu ayda kapasite kullanım oranı \% 120'dir. Bu durum normal maliyetleme yönteminin temel uygulanma mantığı olarak mamullere yüklenecek sabit GÜM payının \% 120 üzerinden yüklenmesini gerektirir. Bu durumda 1.200.000 TL olarak görülen sabit GÜM'ün 1.440.000 TL olarak yüklenmesine ve birim mamul maliyetinin de olması gereken 300 TL'den 320 TL'ye yükselmesine neden olur.

Bu noktada Standardın 13. maddesinde belirtilen iki durumu incelemekte yarar vardır. Bu durumlar şunlardır;

- $\quad$ İlk durum fiili kapasitenin normal kapasiteye çok yakın olduğu durumdur. $\mathrm{ABC}$ işletmesinin Temmuz ayı verileri incelendiği zaman işletmenin fiili kapasitesinin 9.800 birim olarak gerçekleştiği ve bu kapasite miktarının da normal kapasiteye çok yakın olduğu görülür. Öyleyse bu ay için $\mathrm{ABC}$ işletmesinin normal maliyetleme yöntemini kullanmasına gereksinimi yoktur. Bu da işletmenin ilgili ayda ortaya çıkan tüm genel üretim maliyetlerini 
sabit ve değişken ayrımı yapmaksızın doğrudan mamullere yükleyebileceği tam maliyet yöntemini kullanabileceği sonucunu doğurur.

- Diğer bir durum ise yukarıda tartışılan, Standardın aşırı kapasite kullanımı durumunda normal maliyet yöntemi kullanılarak sabit GÜM'lerin artırılmak suretiyle birim maliyetin yükseltilmesine müsaade etmediği ve tam da bu nedenle böyle durumlarda tam maliyet yönteminin kullanılması gerektiği çıkarımı yapılan durumdur. $A B C$ işletmesinin Ağustos ayı verileri incelendiği zaman eğer işletme normal maliyet yöntemini kullanırsa birim sabit genel üretim maliyeti 120 TL (1.440.000/12.000) olacaktır. Ancak standart madde 13 'te bu durumu birim sabit genel üretim maliyetlerinin düşürülerek, mamullerin yüksek maliyetten değerlenmediği bir maliyet yaklaşımının dikkate alınması gerektiğini ifade eder. $\mathrm{Bu}$ yöntem tam maliyet yöntemidir. İșletme \% 120 kapasite kullanmasına rağmen 12.000 birime yüklemesi gereken sabit GÜM pay1 1.200.000 TL olacaktır. Böylelikle birim sabit GÜM payı 100 TL'ye düşecek ve Standartta belirtildiği gibi mamuller olması gereken birim maliyet değerinden değerlenecektir.

\section{SONUÇ VE DEĞERLENDİRME}

Yukarıdaki örnek uygulama ve açıklamalardan şu çıkarımları yapmak mümkündür; $\mathrm{ABC}$ işletmesi eğer Türkiye Muhasebe Standartlarını uygulamak zorunda olan bir işletmeyse Haziran ayında normal maliyet, Temmuz ayında ister normal ister tam maliyet, Ağustos ayında ise tam maliyet yöntemini kullanmak zorundadır. Burada özellik arz eden durum Ağustos ayına ilişkindir. Ağustos ayındaki normal kapasitenin üstünde gerçekleşen üretim normal maliyetten tam maliyet yöntemine geçişi gerektirmiş̧ir. Bu gerekliliğin literatürde daha önce açıklanmamış izahı şu şeklide yapılabilir; temel mantı̆ğ kapasite düzeyi ile bu kapasite düzeyinin oluşmasında önemli bir faktör olan sabit genel üretim maliyetleri arasında kurulacak ilişkiye dayalı bir maliyet yapısı olan normal maliyet yönteminin felsefesini, aşırı kapasite oluşması durumunda tam maliyete dönülmesi ile kaybetmektedir. Eksik kapasite kullanımında mamullerin fazlaca sabit maliyet yükünden arındırmasına karşılık, işletmenin üretim olanaklarının fazlaca yıpranacağı aşırı kapasite kullanım dönemlerinde normal maliyet yönteminin kullanılmayacak olması önemli bir çelişki olarak gözükebilir. Ancak bütçelenmiş sabit maliyetler normal kapasiteye göre planlanmıştır. Bu maliyetler kira, sigorta, amortisman gibi bilinen sabit unsurlardan oluşur. Normal kapasiteyi geçici dönemlerde aşmak bu giderleri doğrudan yükseltmez. Akla aşınma ve yıpranma gelebilir. Bu durum ise amortisman ayırmada üretim miktarı yöntemine göre hareket etmek durumunda ortaya çıkar. Amortisman hesaplamada üretim miktarı esas alınırsa, üretim miktarına göre ayrılacak amortisman gideri sabit bir genel üretim gideri değil, değişken genel üretim gideri unsuru olacaktır.

Sonuç olarak TMS-2 Stoklar Standardına göre karşılaşılabilecek kapasite düzeylerine göre kullanılması gereken yöntemler aşağıda gösterilmiştir.

\begin{tabular}{|l|l|l|}
\hline & Kapasite Düzeyi & Kullanılacak Maliyet Yöntemi \\
\hline Durum 1 & Fiili Kapasite < Normal Kapasite & Normal Maliyet Yöntemi \\
\hline Durum 2 & Fiili Kapasite $\leq$ Normal Kapasite & Tam veya Normal Maliyet Yöntemi \\
\hline Durum 3 & Fiili Kapasite > Normal Kapasite & Tam Maliyet Yöntemi \\
\hline
\end{tabular}


Burada sorun oluşturabileceği düşünülen husus, tabloda 1. ve 2. durum olarak açıklanan, fiili kapasitenin normal kapasiteden düş̧ük olduğu durumlardır. Normal kapasitenin çok altında veya az altında olduğu söylemi göreceli bir duruma işaret eder. Bu durumda Standart işletme yöneticilerine muhasebe politikası seçiminde bir alternatif sunmaktadır. Sözgelimi işletme yönetimi \% 10 ve altı boş kapasiteyi normal kapasiteye yakın olarak değerlendirilebilen bir oran olarak belirleyebilir. Böyle bir kabul düzeyinde $\% 90$ ve üstünde gerçekleşecek kapasite kullanım oranında tam maliyet yöntemi, \% 90 veya altında gerçekleşecek kapasite kullanım oranında gerçekleşecek normal maliyet yöntemini kullanabilir. Tabloda 3. durum olarak gösterilen aşırı kapasite kullanımı durumunda ise Standart, normal kapasitenin aşılmasından hareketle tam maliyet yönteminin kullanılması durumu yukarıda açıklaması yapılan gerekçelerden dolayı hüküm altına alınmıştır.

\section{KAYNAKLAR}

Badem, A. Cemkut - Özbek, Yiğit (2013), “Tam Maliyet İle Normal Maliyet Yöntemlerinin Tms 2 Stoklar Standardı İle VUK Açısından Karşılaştırması Ve Muhtemel Ertelenmiş Vergi Etkisi”, Muhasebe ve Vergi Uygulamaları Dergisi, 6 (2), ss. 65-92.

Badem, A. Cemkut (2014), Üniversitelerde Tam Maliyetleme (Full Costing), Umuttepe Yayınları, İzmit.

Büyükmirza, H. Kamil (2012), Maliyet ve Yönetim Muhasebesi: Tekdüzen'e Uygun Bir Sistem Yaklaşımı, 17. Baskı, Gazi Kitapevi, Ankara.

Erden, Selman Aziz (2004), Üretim Ortamları Maliyet Yönetim Sistemleri İlişkisi ve Stratejik Maliyet Yönetimi, Türkmen Kitapevi, İstanbul.

Gökçen, Gürbüz - Öztürk, Erkan (2017), "Tam Maliyet Ve Normal Maliyet Yöntemlerinin UFRS (TFRS) ve BOBİ FRS'deki Düzenlemeler Çerçevesinde İncelenmesi”, Finans Ekonomi ve Sosyal Araştırmalar Dergisi, 2 (2), ss. 105-114.

Güngörmüs, Ali Haydar - Boyar, Ender (2010), "TMS- 2 Stoklar Standardına Göre, Standart Maliyet Yönteminin Uygulanması", Mali Çözüm Dergisi, 102 (Kasım-Aralık), ss. 109-127.

Haftacı, Vasfi (2013), Yönetim Muhasebesi, Umuttepe Yayınları, İzmit.

Hansen, Don R. - Mowen, Maryanne M. (2006), Cost Management: Accounting and Control, Thomson South-Western, United States of America.

Horngren, Charles T. - Datar, Srikant M. - Rajan, Madhav V. (2012), Cost Accounting: A Managerial Emphasis, Prentice Hall, United States of America.

Marşap, Beyhan - Barış̧̧, Atilla (2014), "TMS-2 Stoklar Standardına Göre Dönüştürme Maliyetlerinin Ürün Maliyetlerine Etkisi” Muhasebe ve Vergi Uygulamaları Dergisi, 7 (1), ss. 1-16. 
Öztürk, Erkan - Güleç, Ömer Faruk (2018), "Normal Maliyetleme Yaklaşımının Gelişimi Ve Uygulanmasına Yönelik Bir İnceleme” Mali Çözüm Dergisi, 148 (Temmuz-Ağustos), ss. 11-27.

Özyapıcı, Hasan (2019), “ TMS 2 Stoklar Standardı'nın Atıl Kapasite Analizine Etkisi”, Muhasebe ve Vergi Uygulamaları Dergisi, 12 (3) ss. 651-666.

213 Sayılı Vergi Usul Kanunu, İlan Tarihi: 04.01.1961, Resmi Gazete No: 10703-1070410705

6102 Sayılı Türk Ticaret Kanunu, İlan Tarihi: 14.02.2011, Resmi Gazete No: 27846

TMS-2 Stoklar Standardı, İlan Tarihi:15.01.2005, Resmi Gazete No: 25701

BOBİ FRS, İlan Tarihi: 29.07.2017, Resmi Gazete No: 30138

KÜMİ FRS,

https://www.kgk.gov.tr/Portalv2Uploads/files/Duyurular/v2/KUMI/KamuoyuGorusun eAcilanlar/K\%C3\%9CM\%C4\%B0\%20FRS\%20Taslak\%20Metin.pdf (Erişim Tarihi:21.11.2019) 